\title{
Cell density and light intensity for Picochlorum sp.
}

\author{
Ngan Tran", Clifford Louime ${ }^{2}$, Duc Tran ${ }^{1, *}$ \\ ${ }^{1}$ International University, HCM-VNU, Vietnam \\ ${ }^{2}$ University of Puerto Rico - College of Natural Sciences - San Juan, PR 00937
}

\section{Email address:}

tnduc@hcmiu.edu.vn (D. Tran)

\section{To cite this article:}

Ngan Tran, Clifford Louime, Duc Tran. Cell Density and Light Intensity for Picochlorum sp.. Plant. Vol. 2, No. 6, 2014 , pp. 68-71. doi: $10.11648 /$ j.plant.20140206.12

\begin{abstract}
A Picochlorum sp. of Trebuxiophycean was previously isolated with the total lipid of $48.6 \%$ of its dry weight (DW), including $27.84 \%$ of docosahexaenoic acid (DHA). For further fundamental studies and application of the alga such as biomass optimization and lipid production for food and energy, optimal physiological conditions of initial cell density and light intensity are necessary to be determined. The obtained data revealed the best growth of Picochlorum sp. was at light intensity of $50 \mu \mathrm{mol}$ photon $/ \mathrm{m}^{2} / \mathrm{s}$ and cell density of $5 \times 10^{6}$ cells $/ \mathrm{ml}$.
\end{abstract}

Keywords: Cell, Density, Growth, Light

\section{Introduction}

Food shortage, climate change, and decrease of fossil fuel availability are global crisis that need alternative sources of nutritional resources and fuel (Chisti 2008, Tran et al. 2014). Microalgal biomass is often rich in products with high nutritional value and pharmaceutical activities and is considered as a good, carbon neutral, renewable energy source (Ordog et al. 2012, Tran et al. 2014). The lipid content and components, as well as proteins, amino acids and vitamins, are greatly different among species/strains, and even within a single strain under various growth conditions (Krienitz and Wirth 2006; Ordog et al. 2012; Ruangsomboon et al. 2013, Tran et al. 2014). An alga Picochlorum sp. was previously isolated and determined in our lab as a potential source for food and oil production (Tran et al. 2014), which this research continues to determine optimal conditions of light intensity and cell density for further fundamental studies and application of the alga such as biomass optimization and lipid production for food and energy.

\section{Material and Method}

\subsection{The Alga and Culture Conditions}

The alga was previously isolated in Vietnam and maintained in our lab using the low cost modified natural seawater medium $0.5 \mathrm{M}$ (MD4) according to Tran et al. (2014). The medium contained natural seawater, supplemented with NPK $0.1 \mathrm{~g} / \mathrm{l}, \mathrm{MgSO}_{4} 1.86 \mathrm{~g} / \mathrm{l}$, EDTA $0.00876 \mathrm{~g} / \mathrm{l}, \quad \mathrm{FeCl}_{3} 0.00049 \mathrm{~g} / \mathrm{l}, \mathrm{MnCl}_{2} \quad 0.00189 \mathrm{~g} / \mathrm{l}, \quad \mathrm{NaHCO}_{3}$ $50 \mathrm{mM}, \mathrm{pH}=7.5$. The alga was cultivated at three different light intensities $\left(30,50\right.$ and $100 \mu \mathrm{mol}$ photon $\left./ \mathrm{m}^{2} / \mathrm{sec}\right)$ in $50 \mathrm{ml}$ flasks at $25^{\circ} \mathrm{C}$ to determine the optimal light which was used to grow the alga at three cell densities of $0.5 \times 10^{7}, 1 \times 10^{7}$, $2 \times 10^{7}, 4 \times 10^{7}$ cells $/ \mathrm{ml}$. All experiments were done in triplicate and repeated at least twice.

Cell number was counted every three days using a light microscope with $0.1 \mathrm{~mm}$ deep counting chamber (Neubauer Haemocytometer), and was calculated by the formula:

$$
\begin{aligned}
& \text { Number of cells } / \mathrm{ml}=\text { total cells counted } \times 10^{4} \times \text { dilution } \\
& \text { factor. }
\end{aligned}
$$

Specific growth rate (G: divisions/day) and cell growth productivity (P: cells/ml/day) were determined using equations according to Levasseur et al. (1993):

$$
\mathrm{G}=\ln \left(\mathrm{N}_{\mathrm{t}} / \mathrm{N}_{0}\right) / \mathrm{t} ; \mathrm{P}=\left(\mathrm{N}_{\mathrm{t}}-\mathrm{N}_{0}\right) / \mathrm{t}
$$

Where: $\mathrm{N}_{\mathrm{t}}$ and $\mathrm{N}_{0}$ are cell density at time $\mathrm{t}$ and time 0 respectively.

\subsection{Statistical Analysis}

All data were calculated with standard error $( \pm$ ER) and analyzed by one-way ANOVA using SPSS 16.0 software. In all cases, the threshold for significance was set at $\mathrm{p}<0.05$. 


\section{Result and Discussion}

\subsection{Optimal Light Intensities}
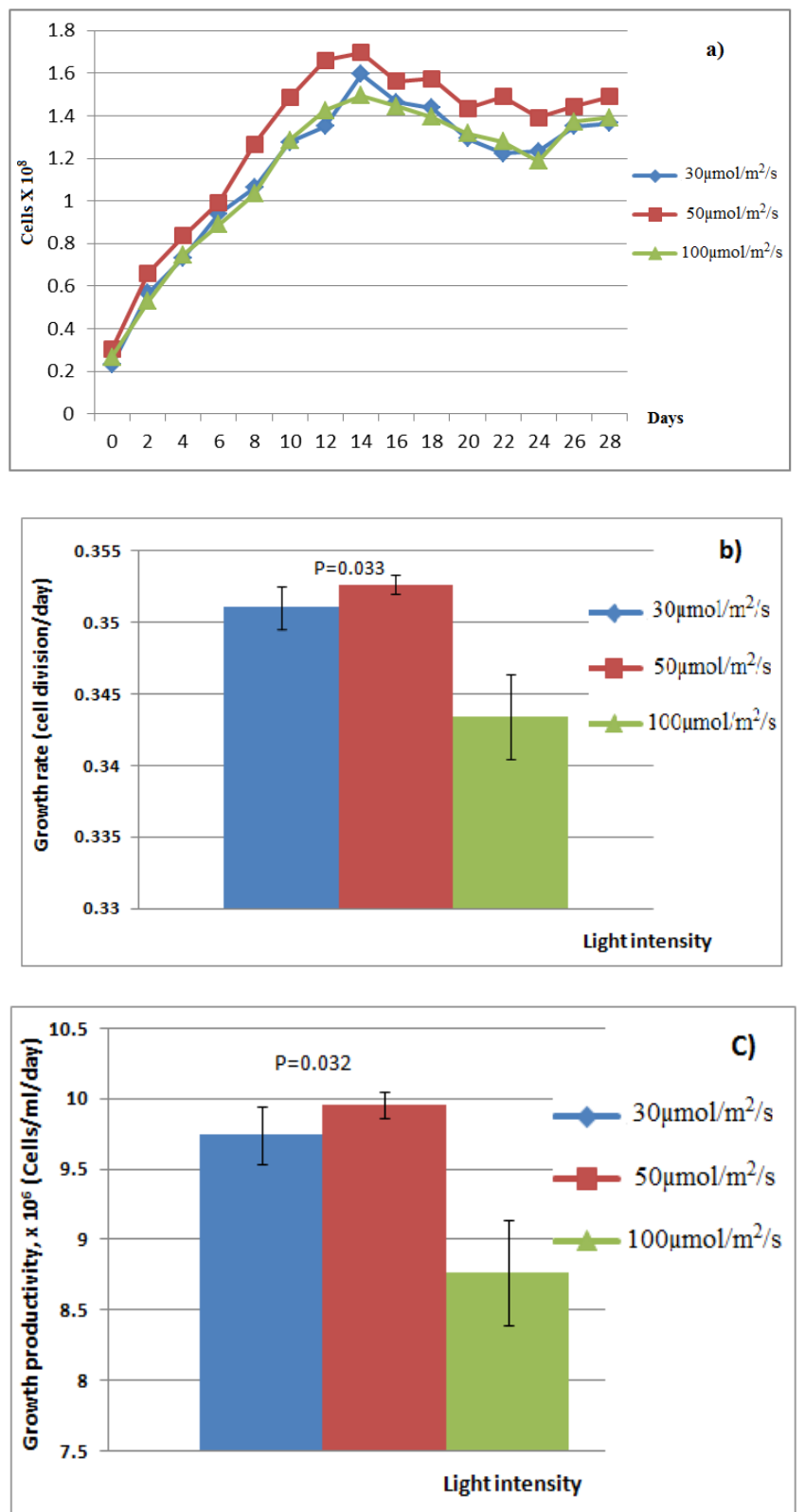

Figure 1. Growth of Picochlorum sp. under different light intensity of 30, 50, 100 umoles photons $m^{-2} s^{-1}$ : growth curve $(a)$, growth rate $(b)$ and growth productivity (c) with significant statistic value $P$

Data of growth curve, growth rate and productivity (Figure 1) indicates Picochlorum sp. grew better at light intensity of $50 \mu \mathrm{mol} / \mathrm{m}^{2} / \mathrm{s}$ than at $30 \mu \mathrm{mol} / \mathrm{m}^{2} / \mathrm{s}$ and $100 \mu \mathrm{mol} / \mathrm{m}^{2} / \mathrm{s}(\mathrm{p}<$ $0.001)$, with respective density of $1.69 \times 10^{8}$ cells $/ \mathrm{ml}, 1.59$ $\mathrm{x} 10^{8}$ and $1.49 \times 10^{8}$ cells $/ \mathrm{ml}$, respectively. There was no difference of growth between light intensity of $30 \mu \mathrm{mol} / \mathrm{m}^{2} / \mathrm{s}$ and $100 \mu \mathrm{mol} / \mathrm{m}^{2} / \mathrm{s}(\mathrm{p}>0.05)$. This indicates both low and high light affect slow growth of Picochlorum sp. Light intensity above $50 \mu \mathrm{mol} / \mathrm{m}^{2} / \mathrm{s}$ could be applied according to gradual increase of cell density, which needs further tests. The growth began declining after 14 days, but maintained rather stable for at least another 2 weeks. Taken together, the optimal light for Pichochlorum was around $50 \mu \mathrm{mol} / \mathrm{m}^{2} / \mathrm{s}$ and should be below $100 \mu \mathrm{mol} / \mathrm{m}^{2} / \mathrm{s}$, which is a common preferable light intensity for most marine as well as fresh water microalgae (Vo et al 2014)

\subsection{Initial Cell Densities}
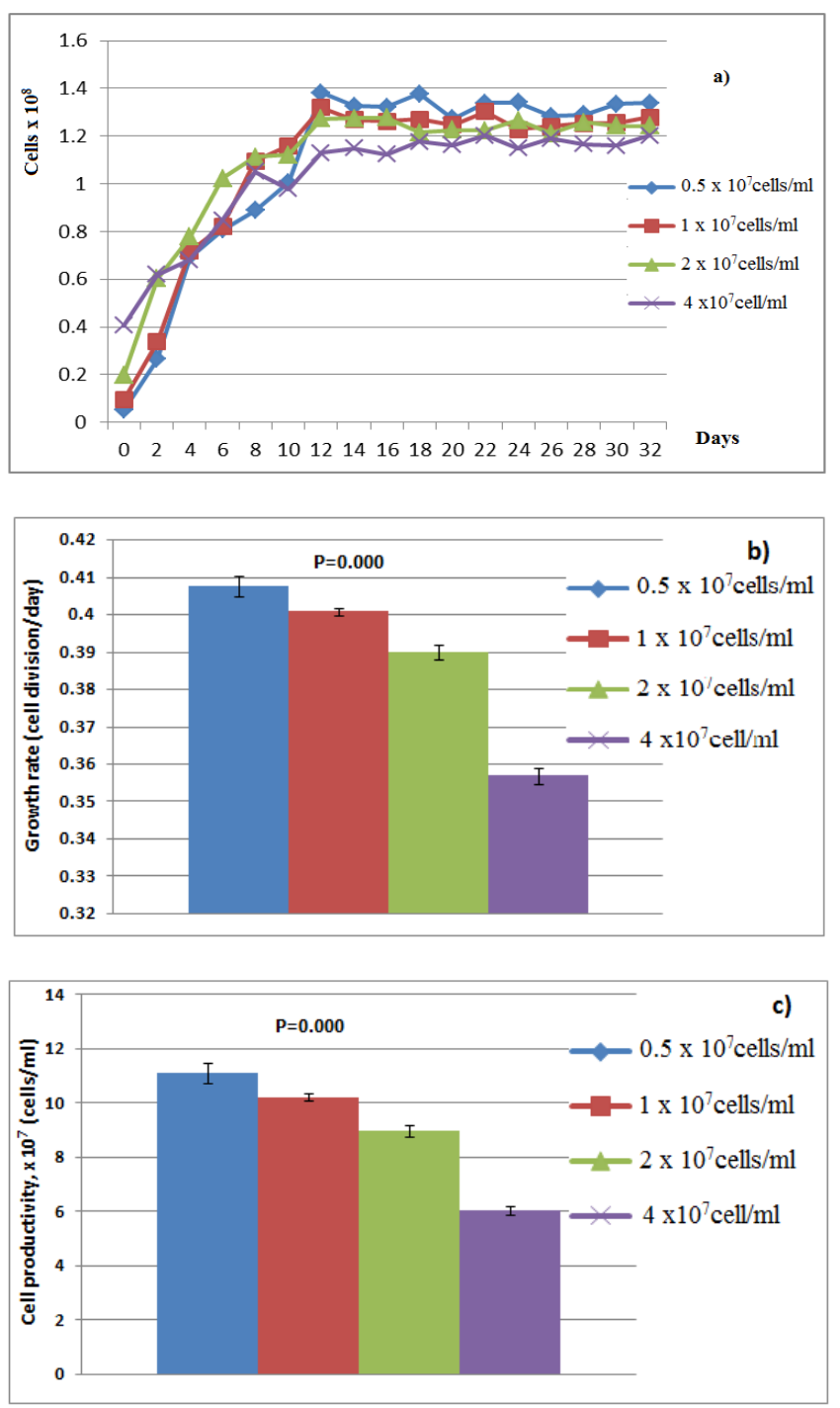

Figure 2. Growth of Picochlorum sp. from different initial cell densities under optimal light intensity of $50 \mu$ moles photons $\mathrm{m}^{-2} \mathrm{~s}^{-1}$ : growth curve (a), growth rate (b) and growth productivity (c) with significant statistic value $P$

Based on the consistent data of growth curve, growth rate and productivity, it revealed that growth of Picochlorum from four initial cell densities was significantly different (Figure 2). The initial cell density of $0.5 \times 10^{7}$ cells $/ \mathrm{ml}$ provided the highest growth performance, which reached $1.38 \times 10^{8}$ cells $/ \mathrm{ml}$ after 12 days; whereas the other initial cell densities of $1 \times 10^{7}, 2 \times 10^{7}$, $4 \times 10^{7}$ cell $/ \mathrm{ml}$ had lower cell densities of $1.32 \times 10^{8}, 1.27 \times 10^{8}$, $1.12 \times 10^{8}$ cell $/ \mathrm{ml}$, respectively. It is probably that cell density below $0.5 \times 10^{7}$ cells $/ \mathrm{ml}$ could support higher growth. This could be appropriately considered for detailed studies of other physiological conditions at lab scale, but not necessary for large scale cultivation as the cell density needs to be 
maintained high for being dominant and resitant to other invading organisms.

Similar to the cell growth data under different light intensities, growth of Picochlorum declined after 14 days, and maintained stable growth afterwards. This is an interesting aspect regarding maintaining high biomass with simultaneous accumulation of secondary metabolites such as lipid, antioxidant etc.

\section{Conclusion}

Light intensity for Pichochlorum sp. should be below $100 \mu \mathrm{mol} / \mathrm{m}^{2} / \mathrm{s}$, and the optimal growth was obtained at around $50 \mu \mathrm{mol} / \mathrm{m}^{2} / \mathrm{s}$. The maximum initial cell density should not be above $0.5 \times 10^{7} \mathrm{cell} / \mathrm{ml}$. However, depending on specific study and application, cell density could be applied lower or higher at lab and large scale, respectivey. The data from this research is a base for further fundamental studies and applications of the alga such as biomass optimization and lipid production for food and energy.

\section{Acknowledgement}

The authors are grateful for the funding of The National Foundation for Science and Technology Development, Vietnam (NAFOSTED) to carry out this research (Funding number: Nafosted/106.16-2011.31).

\section{References}

[1] AOAC, 2002(a). Fat (Total, Saturated, Unsaturated, and monounsaturated) in Cereal Products Acid Hydrolysis Capillary Gas Chromatographic Method, AOAC Method 996.01A.

[2] AOAC, 2002(b). Amino Acids in Feeds Performic Acid Oxidation with Acid Hydrolysis-Sodium Metabisulfite Method. Method 994.12.

[3] AOAC, 2002(c). Tryptophan in Foods and Food and Feed Ingredients Ion Exchange Chromatographic Method. Method 988.15.

[4] Aragao, C. L., E.C. Conceicao, M. T. Dinis, and H. J. Fyhn. 2004. Amino acid pools of rotifers and Artemia under different conditions: nutritional implications for fish larvae. Aquaculture 234: 429-445.

[5] Arnaud, M. F. 2000. The role of microalgae in aquaculture: situation and trends. Journal of Applied Phycology 12: 527-534.

[6] Bligh, E.G., and W.J. Dyer. 1959. A rapid method for total lipid extraction and purification. Canadian Journal of Biochemical and Physiology 37:911-917.

[7] Borowitzka, M. A. 2013. High-value products from microalgae their development and commercialization. Journal of Applied Phycology 25:743-756.

[8] Bradford, M. M. 1976. A Rapid and Sensitive Method for the Quantitation of Microgram Quantities of Protein Utilizing the Principle of Protein-Dye Binding. Analytical Biochemistry 72: 248-254.
[9] Brown, M. R., C. D. Garland, S. W. Jeffrey, I. D Jameson, and J. M. Leroi. 1993. The gross and amino acid compositions of batch and semi-continuouscultures of Isochrysis sp. (clone T.ISO), Pavlova lutheri and Nannochloropsis oculata. Journal of Applied Phycology 5: 285-296.

[10] Chisti, Y. 2008. Biodiesel from microalgae beats bioethanol. Trends in Biotechnology. 26(3): 126-131.

[11] Chitlaru, E. and U. Pick. 1989. Selection and characterization of Dunaliella salina mutants defective in haloadaptation. Plant Physiology, 91: 788-794.

[12] Demirbas, A. 2010. Use of algae as biofuel sources. Energy Conversion and Management. 51: 2738-2749.

[13] Demirbas, F. M. 2011. Biofuels from algae for sustainable development. Applied Energy 88: 3473-3480.

[14] Durmaz, Y., M. Monteiro, N. Bandarra, Ş. Gökpinar, and O. Işik. 2007. The effect of low temperature on fatty acid composition and tocopherols of the red microalga, Porphyridium cruentum. Journal of Applied Phycology 19:223-227.

[15] Felsenstein, J. 1989. PHYLIP - Phylogeny Inference Package, Version 3.2. Cladistics 5: 164-166.

[16] Francisco, J. L. G., M. Goutx, F. L. Figueroa, and F. X. Niell. 1998. Effects of light intensity, CO2 and nitrogen supply on lipid class composition of Dunaliella viridis. Journal of Applied Phycology 10: 135-144.

[17] Hall, T.A. 1999. BioEdit: a user-friendly biological sequence alignment editor and analysis program for Windows 95/98/NT. Nucl. Acids. Symp. Ser. 41:95-98.

[18] Hanaa, H. A., F. K. El Baz and G. S. El-Baroty. 2004. Production of Lipids Rich in Omega 3 Fatty Acids from the Halotolerant Alga Dunaliella salina. Biotechnology 3(1): 102108 .

[19] Harel, M., W. Koven, I. Lein, Y. Bar, P. Behrens, J. Stubblefield, Y. Zohar, and R. A. Place. 2002. Advanced DHA, EPA and ArA enrichment materials for marine aquaculture using single cell heterotrophs. Aquaculture 213:347-362.

[20] Hu, Q., M. Sommerfeld, E. Jarvis, M. Ghirardi, M. Posewitz, M. Seibert, and A. Darzins. 2008. Microalgal triacylglycerols as feedstocks for biofuel production: perspectives and advances. The Plant Journal.54:621-639.

[21] Krientz, L., and M. Wirth. 2006. The high content of polyunsaturated fatty acids in Nannochloropsis limnetica (Eustigmatophyceae) and its implication for food web interactions, freshwater. Limnologica 36(3): 204-210.

[22] Lee, S. J., B. D Yoon, and H. M Oh. 1998. Rapid method for the determination of lipid from the green alga Botryococcus braunii. Biotechnology Techniques 12(7): 553-556.

[23] Lee, Y. K., H. M. Tan, and C. S. Low. 1989. Effect of salinity of medium on cellular fatty acid composition of marine alga Porphyridium cruentum (Rhodophyceae). Journal of Applied Phycology 1: 19-23.

[24] Liang, Y., K. Mai, and S. Sun. 2005. Differences in growth, total lipid content and fatty acid composition among 60 clones of Cylindrotheca fusiformis. Journal of Applied Phycology 17: 61-65. 
[25] Liu, Z. Y., G. C. Wang, and B. C. Zhou. 2008. Effect of iron on growth and lipid accumulation in Chlorella vulgaris. Bioresource Technology 99: 4717-4722.

[26] Muradyan, E. A., G. L. Klyachko-Gurvich, N. N. TsogliL, T. V. Sergeyenko, and N. A. Pronina. 2004. Changes in Lipid Metabolism during Adaptation of the Dunaliella salina Photosynthetic Apparatus to High $\mathrm{CO} 2$ Concentration. Russian Journal of Plant Physiology 51(1): 53-62.

[27] Nguyen, H. D., V. D. Nguyen, T. H. N. Nguyen, T. T. L. Nguyen, and A. M. Nguyen. 2012. Improvement of amino acid determining method". Journal of Science \& Technology Development 14: 27-35.

[28] Ördög, V., A. S. Wendy, P. Bálint, J. V. Staden, and C. Lovász. 2012. Changes in lipid, protein and pigment concentrations in nitrogen-stressed Chlorella minutissima cultures. Journal of Applied Phycology 24:907-914.

[29] Perneta, F., R. Tremblayb, E. Demersc, and M. Roussy. 2003. Variation of lipid class and fatty acid composition of Chaetoceros muelleri and Isochrysis sp. Grown in a semicontinuous system. Aquaculture 221: 393-406.

[30] Takagi, M., Karseno, and T. Yoshida. 2006. Effect of Salt Concentration on Intracellular Accumulation of Lipids and Triacylglyceride in Marine Microalgae Dunaliella Cells. Journal Of Bioscience And Bioengineering 101(3): 223-226.

[31] Renaud, S. M., V. T. Luong, and D. L. Parry. 1999. The gross chemical composition and fatty acid composition of 18 species of tropical Australian microalgae for possible use in mariculture. Aquaculture 170: 147-159.

[32] Renaud, S. M., H. C. Zhou, D. L. Parry, V. T. Luong, and K. C. Woo. 1995. Effect of temperature on the growth, total lipid content and fatty acid composition of recently isolated tropical microalgae Isochrysis sp., Nitzschia closterium, Nitzschia paleacea, and commercial species Isochrysis sp. (clone T.ISO). Journal of Applied Phycology 7: 595-602.

[33] Rodolfi, L., G. C. Zittelli, N. Bassi, G. Padovani, N. Biondi, G. Bonini, and M. R. Tredici. 2009. Microalgae for Oil: Strain Selection, Induction of Lipid Synthesis and Outdoor Mass Cultivation in a Low-Cost Photobioreactor. Biotechnology and Bioengineering 102(1):100-112.

[34] Ruangsomboon, S., M. Ganmanee, and S. Choochote. 2013. Effects of different nitrogen, phosphorus, and iron concentrations and salinity on lipid production in newly isolated strain of the tropical green microalga, Scenedesmus dimorphus KMITL. Journal of Applied Phycology 25:867874.

[35] Scholz, B., and G. Liebezeit. 2013. Biochemical characterisation and fatty acid profiles of 25 benthic marine diatoms isolated from the Solthörn tidal flat (southern North Sea). Journal of Applied Phycology 25:453-465.

[36] Stein, J. 1973. Handbook of Phycological methods, Culture methods and growth measurements. Cambridge University Press.

[37] Tran D., M. Giordano, C. Louime, N. Tran, T. Vo, D. Nguyen, T. Hoang (2014). An isolated picochlorum sp. for aquaculture, food and biofuel. North American Journal Of Aquaculture. DOI: $10.1080 / 15222055.2014 .911226$

[38] Vo T. Vo, D. Tran, 2014. Effects of Salinity and Light on Growth of Dunaliella Isolates. Journal of Applied \& Environmental Microbiology. Vol. 2, No. 5, 208-211. DOI:10.12691/jaem-2-5-2 